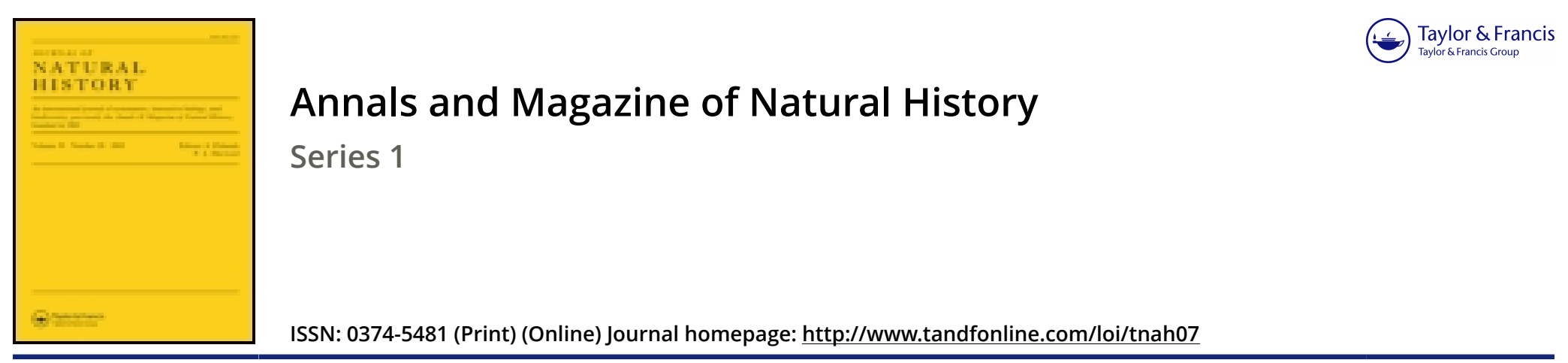

\title{
XLI._On a new genus of Diatomaceæ
}

\section{Rev. M.J. Berkeley \& J. Ralfs Esq.}

To cite this article: Rev. M.J. Berkeley \& J. Ralfs Esq. (1844) XLI.-On a new genus of Diatomaceæ, Annals and Magazine of Natural History, 14:92, 328-329, DOI: 10.1080/037454809495187

To link to this article: http://dx.doi.org/10.1080/037454809495187

$$
\text { 曲 Published online: } 16 \text { Dec } 2009 .
$$

Submit your article to this journal


XLI.-On a new Genus of Diatomaceæ. By the Rev. M. J. Berkeley and J. Ralfs, Esq.

[With a Plate.]

THe Aberdeenshire coast, though far from rich in the higher order of Algæ, has rewarded the researches of Dr. Dickie with one or two species of great interest. In those which are more or less intimately related to Schizonema, on the contrary, several species have occurred no less remarkable for their large size and unusual form than for their beauty. One of these is so anomalous, having a central thread containing frustules, as in Schizonema, surrounded by a highly developed cellular coat, and at the tips extending beyond it, that it has been thought desirable to wait for maturer observation, should another season prove favourable, by a renewed examination of the structure, rather than to publish it as a pendant to the present short notice.

The species which we have now the pleasure of dedicating to its discoverer, Dr. Dickie, is remarkable for its flat ulva-like frond and its pale purplish tint, and cannot be associated with any known genus. Its habit at once removes it from Schizonema, whether taken in a more confined sense and limited to the species with a compound frond, or comprising Micromega and such species as S. Dillwynii: from Encyonema, of which Monema prostratum is a synonym, by its straight, not cymbiform frustules : from Homceocladia by its short, not elongated frustules, as also by its habit; and from Berkeleya again by habit, and by the want of a gelatinous base. Whether Kützing has anything more nearly allied to it will be seen on the publication of his great work on Diatomacea, especially as we have communicated this curious production to him under the name which we are now about to record.

\section{Dickinia, Berk. and Ralfs.}

Frons subgelatinosa, tenera plana deorsum attenuata, undulata, apice obtuso. Frustula oblonga sparsa simplicia vel binata angulis puncto orbiculari notatis. Alga marina vernalis pallide purpureo-alba. Nomen dedimus in honorem Doct. G. Dickie Algarum peritissimi scrutatoris.

Dickieia ulvoides, Berk. and Ralfs.

$H a b$. In shallow pools between high and low water mark with Schizonema comoides and other allied forms. April 20, 1844. Aberdeen, Dr. Dickie.

Frond $1-1 \frac{1}{2}$ inch high, resembling young specimens of Porphyra vulgaris, but of a very pale purplish white hue, a gelatinous consistence, and entirely free from any cellular tissue ; lanceolate, much attenuated below, rather obtuse above, and sometimes, 
though rarely, obovate, very tender and delicate, easily torn, and sometimes perforated with a few roundish apertures, undulated, but not crisped. Frustules single or binate, scattered in the gelatinous substance of the frond without order, oblong, variable in breadth, with the extremities rounded; when fresh marked, according to Dr. Dickie, at the four angles with a round colourless spot. When dry the colouring matter contracts on either side and the pale spots are not visible. There is no trace of any strix. The lateral view is very narrow, simply oblong, with the ends rounded. The colour of the plant when dry is a pale green. The frustules do not appear to be decidedly siliceous, but they have the prismatic form of really siliceous frustules. It appears to be quite a spring species. Every specimen had vanished by the end of the month.

Plate IX: fig. 1. a, Dickieia ulvoides, nat. size, in different stages of growth; $b$, frustules sketched when fresh by Dr. Dickie, highly magnified; $c$, a frustule observed when dry; $d$, lateral view of the same; $e$, a portion of the frond, less highly magnified, showing the simple and binate frustules.

XLII.-Descriptions of Pterochilus, a new genus of Nudibranchiate Mollusca, and two new species of Doris. By Joshua Alder and Albany Hancock, Eisqrs.

Gen. Pterochilus.

Body oblong, nearly linear, tapering behind. Head anterior, terminal, having a flat expanded lobe on each side, forming a kind of veil above the mouth. Jaws corneous. Tentacula two, linear, dorsal, with the eyes behind them. Branchice papillary, elongated, arranged down the sides of the back. Anus on the right side behind the generative organs.

This genus is allied to Eolis and Calliopaa, but differs from both in having the head strongly lobed at the sides. It may also be distinguished from the former by having only two tentacula, and from the latter by the gastric system, which in Calliopaa has two longitudinal vessels down the back, while in Pterochilus there is only one, which is central and undulating. The jaws are triangular horny plates, capped at the anterior angles as in Proctonotus. The tongue is narrow, strap-shaped and denticulated. The auditory capsule has a single otolite.

P. pulcher.-Body nearly linear, pale flesh-coloured, spotted with opake white. Head furnished with a flat, rounded lobe on each side of the mouth, forming a kind of veil. Tentacula short, cylindrical, set much apart on the head. Eyes considerably behind them. Branchia five or six on each side of the back, in a single series, the first two nearly opposite each other; the rest Ann.\& Mag. N. Hist. Vol. xiv., 

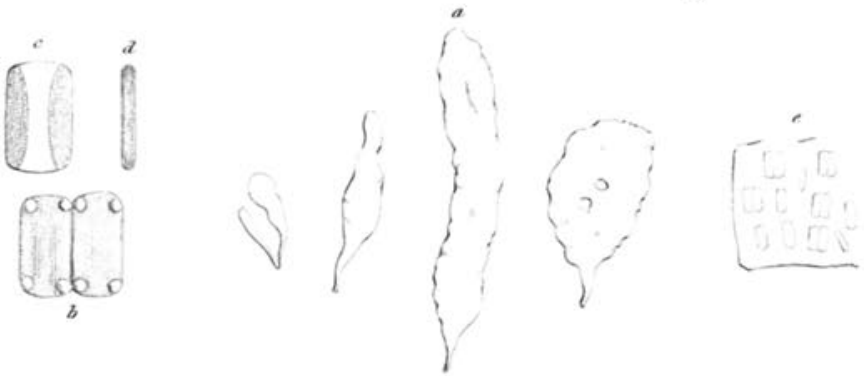

Dickieia ulvoides.

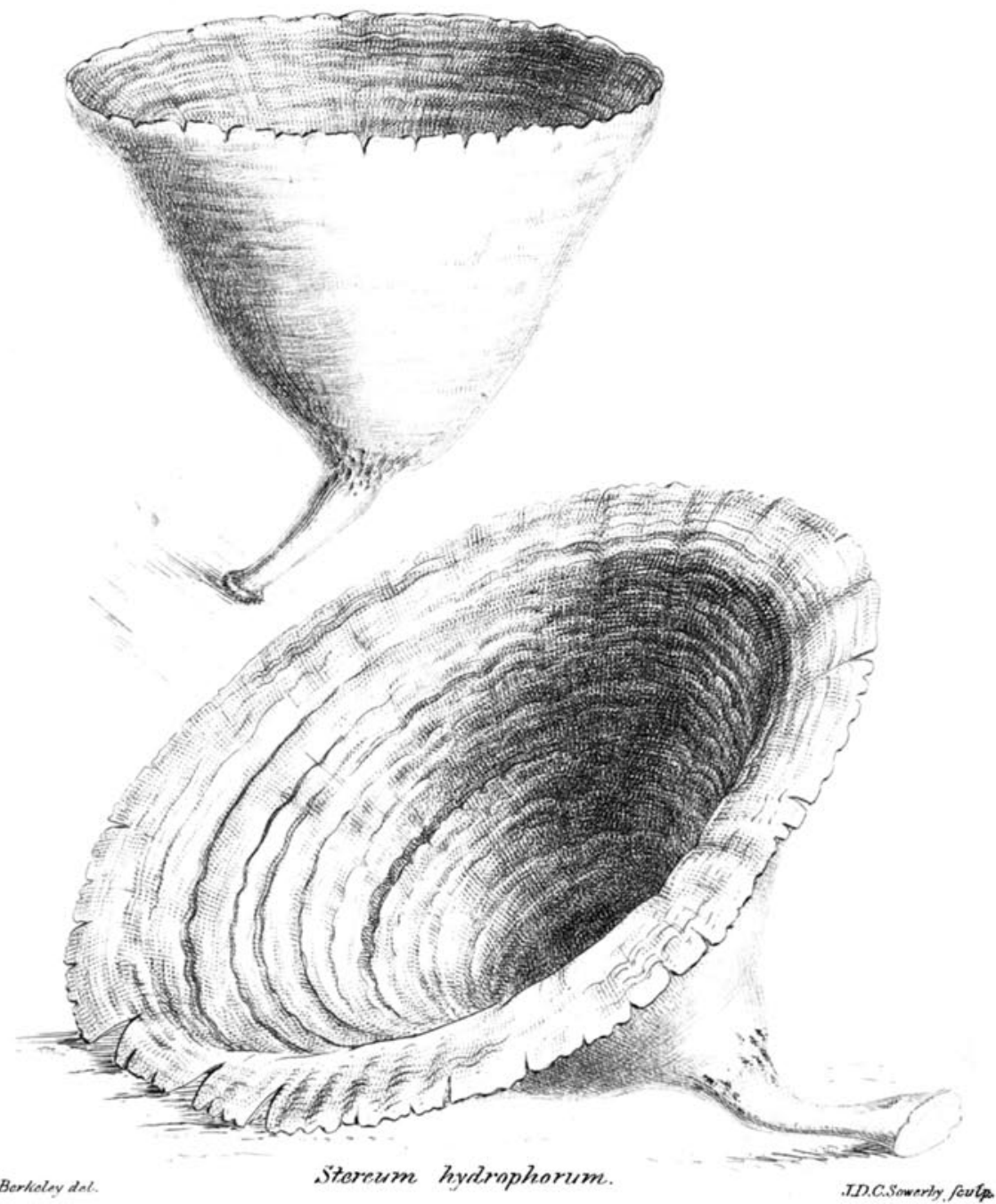

